\title{
PENGGUNAAN DATA SATELIT GIOVANNI DALAM PEMANTAUAN KUALITAS UDARA
}

\author{
Jurusan Teknik Lingkungan, Fakultas Arsitektur Lanskap dan Teknologi Lingkungan, \\ Universitas Trisakti, Jakarta, Indonesia
}

Email korespondensi: sylvania08214061@ @std.trisakti.ac.id

\begin{abstract}
ABSTRAK
Secara umum, pertumbuhan jumlah populasi manusia dan kemajuan teknologi saling terkait dengan tingginya suatu aktivitas manusia menimbulkan masalah pada lingkungan. Permasalahan pada lingkungan yang timbul salah satunya dapat ditinjau lebih lanjut seperti pencemaran udara. Di Indonesia, terutama di Kota Jakarta kendaraan bermotor dan gas buang industri mendominasi timbulnya konsentrasi polutan. Penelitian ini menggunakan studi literatur dan data sekunder yang diperoleh dari software berbasis web Giovanni untuk mencari data curah hujan dan sebaran gas CO di dalam atmosfer wilayah DKI Jakarta selama 6 tahun terakhir. Sejak era satelit dimulai, peneliti dan lainnya telah menggunakan data yang dikumpulkan dari satelit untuk mengamati Bumi. Pemanfaatan citra satelit akan menghemat waktu dan efisien karena datanya dapat diperoleh melalui sebuah aplikasi yang diolah bandingkan survei secara teristerial. Untuk mengakses data satelit cukup mudah mendapatkan hasilnya dan tidak berbayar. Data satelit dapat diakses dari data historis dan jangkauannya cukup banyak, dapat menggambarkan skala kawasan. Data yang diperoleh dalam waktu harian dan bulanan sesuai kebutuhan pengguna.
\end{abstract}

\section{Kata Kunci: Giovanni; Polutan; DKI Jakarta}

\section{PENDAHULUAN}

Secara umum, pertumbuhan jumlah populasi manusia dan kemajuan teknologi saling terkait dengan tingginya suatu aktivitas manusia menimbulkan masalah pada lingkungan. Permasalahan pada lingkungan yang timbul salah satunya dapat ditinjau lebih lanjut seperti pencemaran udara. Pencemaran udara sangat berkaitan dengan pertumbuhan ekonomi yang tinggi dan berdampak buruk bagi kesehatan dan kesejahteraan manusia.

Di Indonesia, terutama Kota Jakarta kendaraan bermotor dan gas buang industri mendominasi timbulnya konsentrasi polutan. Karena banyak permintaan pasar pada bidang ekonomi maka aktivitas pembakaran semakin meningkat dan tidak terkendali. Persebaran polutan ke udara dari sisa pembakaran industri dan kendaraan bermotor bersifat antropogenik. Polutan menimbulkan kadar konsentrasi tinggi jika tidak di reduksi, melainkan langsung di lepas pada udara ambient.

Sejak era satelit dimulai, peneliti dan lainnya telah menggunakan data yang dikumpulkan dari satelit yang mengamati Bumi, tetapi menggunakan kumpulan data berbasis satelit tetap menantang. Memasukkan data ke dalam form umum, menangani volume besar data, memilih perangkat lunak analisis yang tepat, dan menafsirkan hasil memerlukan investasi yang signifikan dalam sumber data computer, tenaga kerja, dan pelatihan.

Tujuan penulisan dari karya ilmiah yaitu mengetahui informasi mengenai cara membuat jurnal yang baik dan benar. Mendeskripsikan cara menguraikan atau membahas pokok masalah yang telah ditentukan dan diteliti. Mendeskripsikan pembatasan ruang lingkup artikel ilmiah tersebut. 


\section{TINJAUAN PUSTAKA \\ Pencemaran Udara}

Pengertian pencemaran udara berdasarkan Undang-Undang Nomor 23 tahun 1997 pasal 1 ayat 12 mengenai Pencemaran Lingkungan yaitu pencemaran yang disebabkan oleh aktivitas manusia seperti pencemaran yang berasal dari pabrik, kendaraan bermotor, pembakaran sampah, sisa pertanian, dan peristiwa alam seperti kebakaran hutan, letusan gunung api yang mengeluarkan debu, gas, dan awan panas.

\section{Pemantauan Kualitas Udara}

Penelitian yang dilakukan oleh Kementerian Negara Lingungan Hidup bekerjasama dengan JICA tahun 1997 menunjukkan bahwa sekitar 70\% kontribusi pencemaran udara berasal dari sektor transportasi, khusus untuk sumber yang berasal dari jalan raya, kontribusi terbesar disumbangkan oleh asap sisa pembakaran gas buang kendaraan bermotor (Menteri Negara Lingkungan Hidup, 2009).

\section{Partikulat Meter 10}

Partikulat Meter (PM) merupakan istilah untuk partikel yaitu padat atau cair yang ditemukan di udara. Partikel dengan ukuran besar dan cukup gelap dapat terlihat dengan kasat mata pada jelaga atau asap pembakaran. Sedangkan partikel yang sangat kecil dapat dilihat dengan mikroskop elektron. Partikel berasal dari berbagai sumber baik mobile dan stasioner (Anonim, 2013).

Aerosol optical depth (AOD) oleh MODIS dan MISR digunakan untuk mengembangkan beberapa model statistik termasuk model multi-regresi linier dan non-linear (Agustine, 2017). PM adalah partikel tersuspensi yang merupakan campuran partikel solid dan droplet cair. Karakteristik dan pengaruh potensial materi partikulat terhadap kesehatan tergantung pada sumber, musim, dan keadaan cuaca (Faisalet al., 2012).

\section{Karbon Monoksida}

Karbon monoksida dengan rumus kimia C-O, adalah gas yang tak berwarna, tak berbau, dan tak berasa. erdiri dari satu atom karbon yang secara kovalen berikatan dengan satu atom oksigen. Dalam hubungan ini, ada dua ikatan dan satu ikatan antara atom dan oksigen. Karbon monoksida dihasilkan dari permukaan yang sempurna. Efek keracunan dari gas tersebut dapat mengakibatkan keracunan pada sistem syaraf pusat dan jantung (Perdana et al., 2013).

Molekul CO memiliki panjang ikat $0,1128 \mathrm{~nm}$. Perbedaan muatan formal dan elektronegativitas saling meniadakan, sehingga terdapat momen dipol yang kecil dengan kutub negatif di atom karbon walaupun oksigen memiliki elektronegativitas yang lebih besar. Elektronegativitas karbon yang lebih rendah menghasilkan awan elektron yang lebih baur, sehingga menambah momen dipol. Ini juga merupakan alasan mengapa kebanyakan reaksi kimia yang melibatkan karbon monoksida terjadi pada atom karbon, dan bukannya pada atom oksigen. (Anonim, 2018)

\section{Lapisan Ozon}

Lapisan ozon adalah lapisan di atmosfer pada ketinggian 20-35 km di atas permukaan Bumi yang mengandung molekul-molekul ozon. Konsentrasi ozon dilapisan ini mencapai 10 ppm dan terbentuk akibat pengaruh sinar ultraviolet Matahari terhadap molekul-molekul oksigen.

Lapisan ozon menyerap 97 sampai 99 persen frekuensi menengah sinar ultraviolet Matahari (panjang gelombang dari sekitar $200 \mathrm{~nm}$ hingga $315 \mathrm{~nm}$ ), yang sebaliknya berpotensi merusak kehidupan yang terpapar di dekat permukaan. (Karin.L.Gleason 2008)

\section{Satelit Giovanni}

Menggunakan set data penginderaan jauh satelit dapat menjadi tugas yang menakutkan. Giovanni, alat berbasis web, memfasilitasi akses, visualisasi, dan eksplorasi untuk banyak set data ilmu bumi NASA. Menggambarkan kemampuan-kemampuan Giovanni terbaru dengan contoh-contoh, dan kami mendiskusikan rencana masa depan potensial untuk sistem inovatif. Giovanni menyediakan akses ke berbagai set data satelit, terkonsentrasi terutama di bidang komposisi atmosfer, dinamika 
atmosfer, pengendapan global, hidrologi, dan radiasi matahari. Lebih dari 1.600 variabel saat ini tersedia di Giovanni. Pengguna yang melakukan pencarian segi dapat memfilter variabel berdasarkan misi satelit (TRMM, Global Precipitation Measurement (GPM)), instrumen, resolusi spasial atau temporal, atau kategori lainnya.

Tabel 1. Hasil Penelitian Terdahulu

\begin{tabular}{|c|c|c|}
\hline Judul Paper, tahun & Penulis & Hasil Penelitian \\
\hline $\begin{array}{l}\text { Visualization, Exploration, } \\
\text { And Model Comparison of } \\
\text { Nasa Air Quality Remote } \\
\text { Sensing Data Giovanni, } \\
2009\end{array}$ & Ana I. Pardos & $\begin{array}{l}\text { - } \mathrm{PM}_{2,5} \text { menggunakan grid dan data model GOCART. } \\
\text { - Layanan Giovanni seperti time series, plot korelasi, } \\
\text { dan scatter plot juga memungkinkan pengamatan } \\
\text { satelit. } \\
\text { - Peta, dan grafik Giovanni lainnya juga dapat } \\
\text { divisualisasikan melalui alat seperti Google Earth, } \\
\text { dan mengaktifkan Tampilan 3D dari AS dan kualitas } \\
\text { udara global. }\end{array}$ \\
\hline $\begin{array}{l}\text { Visualization of A-Train } \\
\text { Vertical Profiles Using } \\
\text { Google Earth, } 2008\end{array}$ & Ajiun Chen & $\begin{array}{l}\text { - Citra vertikal kemudian dipotong menjadi irisan } \\
\text { kecil yang mewakili } 15 \text { waktu satelit (jarak tanah } \\
\text { sepanjang } 103 \mathrm{~km} \text { ). } \\
\text { - Setiap bagian kecil, sebagai tekstur, dimasukkan ke } \\
\text { dalam model COLLAborative Design Activity } \\
\text { (COLLADA) umum tiga dimensi (3-D). }\end{array}$ \\
\hline $\begin{array}{l}\text { NASA Giovanni: A Tool } \\
\text { for Visualizing, Analyzing, } \\
\text { and Inter-Comparing Soil } \\
\text { Moisture Data, } 2014\end{array}$ & William Teng, at. al & $\begin{array}{l}\text { - Saat ini sedang digunakan oleh USDA WAOB, } \\
\text { sebagai bagian dari salah satu proyek yang } \\
\text { mendukung pengembangan portal. } \\
\text { - Untuk komunitas pendidikan, portal akses } \\
\text { Giovanni telah digunakan inclassrooms, workshop. }\end{array}$ \\
\hline
\end{tabular}

\section{METODE}

1. Pengambilan data curah hujan dan sebaran konsentrasi $\mathrm{CO}$

Proses pengambilan data curah hujan di wilayah Jabodetabek pada periode 2012-2018 diunduh dari Tropical Rainfall Measuring Mission (TRMM). Sedangkan data sebaran konsentrasi CO diunduh dengan menggunakan software Giovanni.

2. Analisis trendline konsentrasi CO

Setelah data konsentrasi CO selama 6 tahun didapat, dibuat grafik trendline dengan menganalisis kecenderungan garis rata-rata konsentrasi $\mathrm{CO}$ yang terjadi.

3. Analisis Pola distribusi CO

a. Analisis temporal curah hujan Dalam tahap ini, dengan menggunakan data curah hujan akan dihasilkan pembagian musim berdasarkan intensitas rataan curah hujan selama 6 tahun.

b. Analisis spasial dan temporal konsentrasi CO Setelah pembagian musim berdasarkan intensitas curah hujan dilakukan, nilai konsentrasi CO akan dibandingkan di tiap musimnya, sehingga dapat ditentukan musim dengan besar konsentrasi CO tertinggi dan terendah. Lalu sebaran konsentrasi CO di wilayah Jabodetabek akan terlihat dengan titik koordinat sehingga dapat ditentukan wilayah dengan besar konsentrasi CO tertinggi dan terendah.

4. Visualisasi hasil data dengan aplikasi ArcGIS Petelah pengolahan data sebaran CO, lalu overlay ke dalam peta administrasi Jabodetabek dengan menggunakan aplikasi ArcGIS. Sehingga dapat dilihat sebaran konsentrasi CO pada wilayah penelitian.

5. Pemaparan hasil analisis

Hasil dari proses analisis lalu dipaparkan dan ditarik kesimpulan mengenai pola distribusi konsentrasi CO di daerah Jabodetabek. 


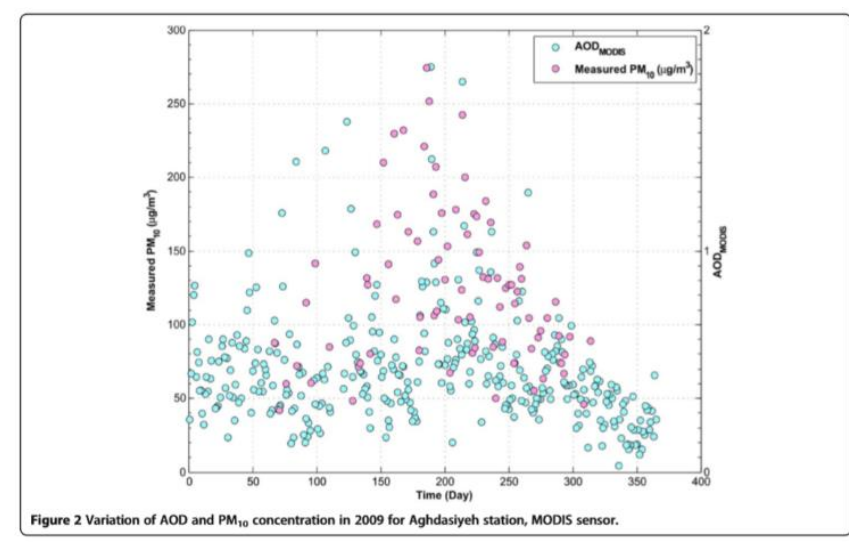

Gambar 1. Sebaran Visualisasi AOD

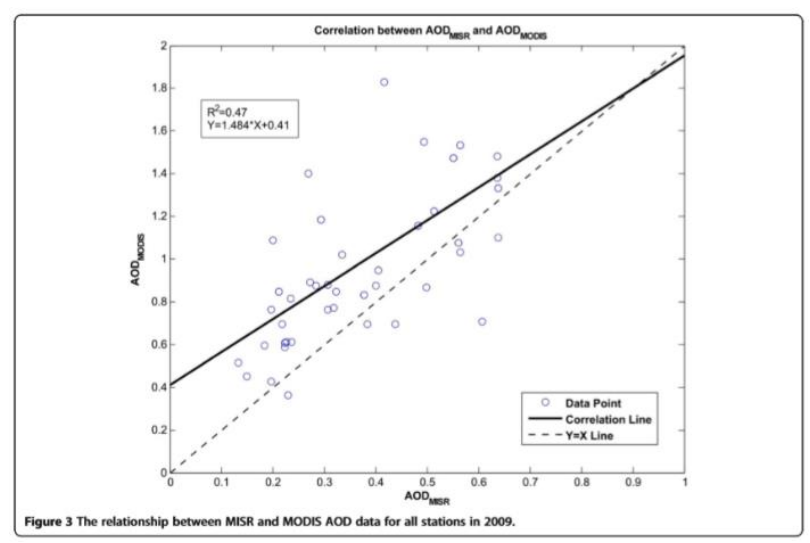

Gambar 2. Hubungan Antara MSR dan MODIS AOD

\section{PENUTUP}

Terjadi penurunan pada grafik trendline gas $\mathrm{CO}$ dimana nilai total besar gas $\mathrm{CO}$ di atmosfer wilayah Jabodetabek memiliki nilai tertinggi sebesar $0.015 \mu \mathrm{g} / \mathrm{m}^{3}$ yang terjadi di bulan Februari 2005 dan nilai terendah terjadi pada bulan April 2013 sebesar $-0.006 \mu \mathrm{g} / \mathrm{m}^{3}$.

Pola distribusi sebaran gas CO di atmosfer wilayah Jabodetabek dipengaruhi oleh curah hujan pada wilayah tersebut. Tetapi nilai sebaran gas $\mathrm{CO}$ lebih rendah dari pada musim kemarau dibandingkan pada saat musim hujan. Hal ini dikarenakan terjadi banyak gangguan pengambilan data CO dari satelit aura terkait kondisi meteorologi sehingga sering terjadi kesalahan pola algoritma pada pengambilan data.

DKI Jakarta, Kota Tangerang, Kabupaten Tangerang, Kota Bekasi, dan Kabupaten Bekasi adalah wilayah dengan rata-rata nilai total konsentrasi CO tertinggi pada Jabodetabek.

\section{DAFTAR PUSTAKA}

Agustine, I. Trend Analysis of Particulate Matter Less Than 10 Micron (PM10) to Ambient Air Quality of Jakarta and Palembang. Thesis. Dept. Environmental Engineering, Universitas Trisakti. Jakarta, Indonesia, 2017

Anonim. 2018. Profil atau Gambaran Kota Jakarta. Diakses pada 08 Agustus 2018 darihttps://id. wikipedia.org/wiki/Daerah_Khusus_Ibukota_Jakarta

Anonim. 2013. Partikulat Meter 10. Diakses pada 29 Juli 2018 dari https://environmental chemistry.wordpress.com/2013/01/18/particulate-matter-pm-10/.

Anonim. 2017. Partikulat Meter. C.P Environmental. Micronics Engineered Filtration Group. Diakses pada 08 Agustus 2018 dari https://www.cpenvironmental.com/2017/03/09/ particulate-matter/

Anonim. 2018. Karbon Monoksida. Diakses pada 27 Juli 2018 dari https://id.wikipedia.org/ wiki/Karbon_monoksida

Berrick, SW, dkk. (2009), Giovanni: Visualisasi dan analisis sistem berbasis layanan data berbasis Web, IEEE Trans. Geosci. Remote Sens., 47 (1), 106-113, Diakses pada tanggal 28 Juli 2018 https://doi.org/10.1109/TGRS. 2008.2003183.

Chen A. at, al. 2008. Visualization of A-Train Vertical Profiles Using Google Earth. Diakses pada 09 Agustus 2018 dari http://citeseerx.ist.psu.edu/viewdoc/download?doi=10.1.1.461. $160 \&$ rep=rep $1 \&$ type $=$ pdf 
Faisal F, Yunus F, Harahap F. 2012. Dampak asap kebakaran hutan pada pernapasan. CDK. 39(1): 31-35.

I. Ana, Prados. 2008. Visualization, Exploration, And Model Comparison of Nasa Air Quality Remote Sensing Data Via Giovanni. Joint Center for Earth Systems Technology. University of Maryland Baltimore County, Baltimore, MD, USA

Karin.L.Gleason. 2008. Stratopheric Ozone Monitoring and Research In NOAA Diakses pada 18 Oktober 2018 dari http://www.ozonelayer.noa.gov/science/basics.htm

Perdana A, Rochim AF, Widianto ED. 2013. Purwarupa sistem pemantau dan peringatankadar gas karbon monoksida $(\mathrm{CO})$ pada kabin mobil berbasis mikrokontroler atmega 8 . Jurnal Teknologi dan Sistem Komputer, 2(1):34-5.

Sotoudeheian and Arhami Journal of Environmental Health Science \& Engineering 2014, 12:122 Diakses pada 29 Juni 2019 dari http://www.ijehse.com/content/12/1/122

Teng W. 2014. NASA Giovanni: A Tool for Visualizing, Analyzing, and Inter-Comparing Soil Moisture Data. Diakses pada 08 Agustus 2018 dari https://ntrs.nasa.gov/archive/nasa /casi.ntrs.nasa.gov/20140009183.pdf 